\title{
Sanín Cano y España: antiimperialismo, americanismo y las tesituras de un congreso frustrado*
}

por

\author{
Manuel Andrés García ${ }^{1}$ \\ Universidad de Huelva
}

\begin{abstract}
Baldomero Sanín Cano es, sin lugar a dudas, uno de los eruditos más relevantes de la intelectualidad latinoamericana contemporánea. Sus múltiples inquietudes hicieron que dejase una huella transversal en campos tan diversos como el ensayo, el periodismo, la crítica literaria, la educación o la política. Este artículo indaga en el ámbito ideológico del autor y, más concretamente, en su vertiente unionista continental, manifiesta en sus constantes críticas al expansionismo estadounidense. Partiendo de una prospectiva sobre la personalidad, formación y experiencia politica de Sanín, el trabajo incide en lo que fue la manifestación de su antiimperialismo militante dentro de los medios españoles $y$, en particular, durante su corresponsalía en Madrid, de 1922 y 1924, para el diario argentino La Nación. Finalmente pasaremos a analizar el impacto que tuvo su propuesta para celebrar un congreso iberoamericano con el que aunar posturas frente a las resoluciones de la Conferencia de Génova.
\end{abstract}

Palabras ClaVe: Baldomero Sanín Cano; antiimperialismo; americanismo; panamericanismo; hispanoamericanismo; América Latina; nacionalismo continental.

Cómo Citar este artículo / Citation: Andrés García, Manuel, "Sanín Cano y España: antiimperialismo, americanismo y las tesituras de un congreso frustrado", Revista de Indias, LXXX/279 (Madrid, 2020): 541-571. https://doi.org/10.3989/revindias.2020.016.

Baldomero Sanín Cano consta como uno de los eruditos más reputados de la historia de Colombia, pero también como una figura de irregular reconoci-

* Este trabajo forma parte del proyecto I+D+i "España como escenario. Diplomacia y acción cultural en la formación de redes transnacionales con América (1914-1945)" (PGC2018094231-B-I00), financiado por el Ministerio de Ciencia, Innovación y Universidades en la convocatoria de 2018.

1 manuel.andres@dhis2.uhu.es, ORCID iD: https://orcid.org/0000-0001-8771-8653 de uso y distribución Creative Commons Reconocimiento 4.0 Internacional (CC BY 4.0). 
miento, con mayor trascendencia en el ámbito intelectual que en el público y una notoriedad que, sorprendentemente, llegaría a ser superior en otros países que en el suyo propio.

Los motivos de tal paradoja serían diversos. Por una parte, hablamos de un autor sumamente prolífico, pudiendo encontrar artículos suyos en periódicos y revistas como El Tiempo de Bogotá; el suplemento semanal del Time de Londres; la también londinense - aunque con impronta colombiana-Hispania; la costarricense Repertorio Americano ${ }^{2}$; la francesa La Revue Sud-Américaine; de Argentina, entre otras, en La Nación, Caras y Caretas, Babel, La Revista de América y Nosotros; en España, en El Sol, España, La Voz, Hojas Selectas, Nuevo Mundo, Nuestro Tiempo... Tal proliferación describe un perfil internacional que relativizaría la fama que pudiera tener en su país al quedar inserta en un marco mucho más amplio. Pero, además, hablamos de una personalidad cuyas peculiaridades lo convertirían en atípico, abordando temáticas totalmente alejadas del tradicionalismo cultural colombiano y a literatos de una modernidad tal que muchos de ellos serían dados a conocer de su mano.

El vanguardismo de Sanín ha llevado a alguno de sus estudiosos a valorarlo como un ensayista con una sensibilidad mucho más contemporánea que la de sus coetáneos ${ }^{3}$. No es que con ello se haya pretendido ubicar al ensayista como un hombre fuera de su tiempo ya que, por el contrario, nunca dejó de implicarse en aquellas causas que consideró dignas de su compromiso. La afirmación, en realidad, iría enfocada hacia lo que sería su particular visión de la cultura y sus inquietudes intelectuales. Visión e inquietudes que, en todo caso, no le llevarían a desentenderse de los problemas políticos, sociales y económicos por los que pasaría su país y el mundo en general.

Dentro de las distintas coyunturas por las que transitó Sanín hay una particularmente interesante que es su relación con el hispanoamericanismo y su vertiente antiimperialista. El antiimperialismo veintesco, en sus muy diversas corrientes de pensamiento y expresión, careció de una homogeneidad ideológica, conceptual e instrumental, lo que se traduciría en una disyuntiva entre aquellos autores hispanoamericanos que siguieron identificando «lo nacional» con la idea decimonónica del Estado-Nación y los que, impulsados en mayor o menor medida por las circunstancias, plantearían un nacionalismo continental como aspiración común ${ }^{4}$.

2 Juan Gustavo Cobo Borda, tomando como fuente a García Monge, señalaría cómo en esta publicación, hasta 1948, habían reproducido alrededor de 155 artículos del escritor. Cobo también suscribe cómo, pese a no ser una preocupación en Sanín la publicación de libros, al final de sus días contaba con diez títulos en su haber. Sanín Cano, 1978: IX-X.

3 Triviño Anzola, 1998: 137.

4 Pita González y Marichal, 2012: 9. 
Este último objetivo estaría íntimamente relacionado con el propósito hispanoamericanista de conformar y promover una comunidad cultural entre España y las repúblicas americanas, en el convencimiento - parafraseando a Isidro Sepúlveda - de que la proyección sinérgica de semejante colectivo tendría un potencial muy superior al de la suma de las distintas fuerzas por separado $^{5}$. Tal deseo, como no podía ser de otro modo, chocaría con el antihispanismo militante, un movimiento que, pese a su fragmentación ${ }^{6}$, haría causa común en el rechazo a España y su legado; cuánto más, en la refutación de todo proyecto integrador en el que concurriese la antaño metrópoli.

Posicionamientos de este tipo contrastarían con el de Sanín, quien llegaría a glosar a España como «nación hispano-americana» en una célebre conferencia enunciada en Madrid, el 12 de abril de 1924, en las instalaciones de Unión Ibero-Americana ${ }^{7}$. Es este un detalle relevante por estar inserto en una tesitura particularmente compleja en la que concurrirían dos prospectivas unitarias pero divergentes: panamericanismo e hispanoamericanismo. La una, sostenida por unos Estados Unidos en plena expansión política, económica y financiera al sur de sus fronteras; la otra, voceada desde una España severamente afectada por la derrota de 1898 y que, incapaz de sumarse en igualdad al concierto imperialista europeo ${ }^{8}$, haría del discurso americanista una de las líneas maestras de su política exterior.

El contexto en el que se desenvolvieron ambos doctrinarios fue determinante a la hora de recabar apoyos. Si a lo largo del XIX España todavía generaba desconfianza en las cancillerías latinoamericanas, su calamitosa derrota a manos de los Estados Unidos anunciaría un cambio de tiempo marcado por el ya incuestionable declive español, la validación de la hegemonía norteamericana en el continente y la ratificación del Coloso del Norte como nuevo actor principal dentro del concierto internacional.

5 Sepúlveda, 2005: 11.

6 Sepúlveda llega a distinguir hasta tres corrientes dentro del antihispanismo: la europeísta; la monroísta y la indigenista. Sepúlveda, 1994: 185-214.

7 «En concepto de Napoleón, África comenzaba en los Pirineos [...] No; España no es África, ni tampoco Europa; España es una nación hispano-americana». Baldomero Sanín Cano, "Las revoluciones hispano-americanas", Unión Ibero-Americana, junio 1924, 9. Accesible online.

8 Palmira Vélez, mentando a Halperín, habla de un «imperialismo del pobre» que, si bien no desdeñaría las relaciones económicas, no haría especial hincapié en ellas. No obstante, a mi parecer, no es aventurado el análisis del historiador argentino al resaltar el trasfondo económico solapado en un discurso primordialmente cultural e historicista, pero con intenciones mucho más concretas y materiales en aquellos países con importantes colonias emigrantes hispanas. Vélez, 2007: 164. Halperín Donghi, 1987: 89. 
La supremacía estadounidense se asentó sobre una estrategia injerencista que, si bien supeditó a buena parte de los gobiernos latinoamericanos, también generó fuertes críticas al sur de sus fronteras, sobre todo entre los sectores intelectuales. Dicha resistencia tuvo un marcado acento antiimperialista, pero también incluyó la reivindicación de aquellos elementos que resaltaban la cercanía histórica y cultural de los países afectados, presentando el intervencionismo de Washington no como algo circunscrito a quienes lo padecían puntual o periódicamente sino como parte de un problema común.

La apelación a un sentir colectivo llevaría a muchos intelectuales hispanoamericanos a valorar la condición vinculante de España y su legado. Casos hubo, como el de Rubén Darío, que, habiéndose significado por sus simpatías hacia el independentismo cubano, pasarían a criticar acerbamente la intervención norteamericana, acercándose a una España «agredida por un enemigo brutal, que lleva como enseña la violencia, la fuerza y la injusticia» ${ }^{9}$. Tal dinámica acabaría aunando, de manera habitual, el sentimiento antiimperialista con el ensalzamiento de la tradición hispánica del continente, reforzando uno de los pilares fundamentales del hispanoamericanismo con el aporte de autores que, de otro modo, tal vez hubiesen tenido una relación distinta con dicho movimiento.

Este artículo versa, precisamente, sobre la relación de un Sanín que aunaría en sí un ostensible sentimiento antiimperialista con un marcado unitarismo hispanoamericano. Un Sanín cuyo cosmopolitismo - manifiestamente europeísta - ha sido usualmente confrontado con el hispanismo de sus iguales conservadores, pero que, sin embargo, mantendría una intensa relación con autores y publicaciones peninsulares. Y un Sanín que, durante su corresponsalía en Madrid para La Nación de Buenos Aires, entraría de lleno en las cuitas del hispanoamericanismo local, llegando a proponer la celebración de un congreso que pondría de manifiesto las dificultades del movimiento para consolidarse frente al panamericanismo.

El trabajo se divide en dos partes y un último apartado de conclusiones, analizando, en el primer punto, la experiencia adquirida con el gobierno de Rafael Reyes y sus primeras manifestaciones antiimperialistas en revistas españolas; en el segundo, sus relaciones con el hispanoamericanismo español, los motivos que le impulsaron a proponer la celebración de un congreso hispanoamericano y sus repercusiones. No ahondaremos, por cuestiones de espacio, en aspectos que complementarían indudablemente la investigación

9 El párrafo pertenece a su artículo "El triunfo de Calibán”, publicado el 20 de mayo de 1898 en El Tiempo de Buenos Aires y el 1 de octubre de ese mismo año, bajo el título "Rubén Darío combatiente", en El Cojo Ilustrado de Caracas. Andrés García, 2014: 599. 
como los antecedentes y evolución del movimiento hispanoamericanista ${ }^{10} \mathrm{o}$ la influencia, en el debate ideológico, de otros movimientos cercanos en interés o vinculados en su orientación - aun con propósitos diferenciadoscomo el latinoamericanismo. No obstante, no está de más referir trabajos como los de Alexandra Pita o Miguel Barrios para vislumbrar la influencia diversa de dicho movimiento y perfilar, de forma nítida, los matices de un contexto intelectual particularmente complejo ${ }^{11}$.

Queda señalar, por último, que las fuentes utilizadas son esencialmente periodísticas, por ser este el medio en el que más se desenvolvió Sanín, profesionalmente hablando, así como por el seguimiento que harían de sus comentarios las distintas cabeceras españolas.

\section{Los ResColdos de PANAMÁ: IDEOlOgía, EXPERIENCIA DE GOBIERNO Y ANTIIMPERIALISMO TEMPRANO}

A pesar de que Sanín sufrió un largo periodo de omisión tras su muerte - algo que criticaría amargamente Rafael Maya ${ }^{12}$ - lo que no puede negarse es que, con el tiempo, su figura ha ido encontrando estudiosos que han ayudado a entender su obra y evolución desde distintas perspectivas, por no hablar de aquellos textos — como el De mi vida y otras vidas - en los que el propio Sanín echó la mirada atrás para recordar episodios y personas que, de un modo u otro, habían dejado huella en él. Es por ello que no haremos una introduc-

10 Tendríamos que hablar, incluso, de su diversidad. Es habitual la asimilación del hispanoamericanismo como un movimiento de corte conservador, asumiendo el fruto de su deriva - sobre todo en la época franquista - como expresión absoluta e inalterable de su naturaleza. Sin embargo, la existencia de un hispanoamericanismo de talante progresista ya sería distinguida por Sepúlveda en 1994, significando su vinculación con el krausismo frente a una vertiente conservadora que tomaría a Menéndez Pelayo como uno de los principales referentes del aparato teórico panhispanista. Entre los autores que merece la pena consultar para un mayor conocimiento del movimiento y sus efectos en el marco identitario español e hispanoamericano resaltarían —además de Sepúlveda y entre otros - David Marcilhacy, y su Raza hispana. Hispanoamericanismo e imaginario nacional en la España de la Restauración; Aimer Granados, con distintas aportaciones entre las que destaca Debates sobre España. El hispanoamericanismo en México a fines del siglo XIX; o, de Felipe Gracia Pérez, su Hijos de la Madre Patria. El hispanoamericanismo en la construcción de la identidad nacional colombiana durante la Regeneración (1878-1900).

11 En el caso de Barrios, con El latinoamericanismo en el pensamiento político de Manuel Ugarte. En el de Pita, con La Unión Latino Americana y el boletín Renovación. Redes intelectuales y revistas culturales en la década de 1920.

12 Maya, 1961: 19. 
ción biográfica al uso ni insistiremos, en la medida de lo posible, en aquellos aspectos que ya hayan sido tratados con anterioridad por otros especialistas, procurando en esos casos citar los autores y obras que mayor información puedan proveer al respecto. Otra cosa es la necesidad de incidir en la faceta ideológica del escritor, un atributo tratado, por lo general, de manera accesoria y que, sin embargo, resulta fundamental para entender, políticamente hablando, la esencia de sus convicciones y el germen de su motivación.

De todos es conocida la experiencia de gobierno de Sanín durante la presidencia de Rafael Reyes, al igual que su inquebrantable afiliación liberal ${ }^{13}$. Que un liberal como Sanín acabase formando parte de un gabinete conservador devino, paradójicamente, de la voluntad del mandatario de abrir su gabinete a aquellos adversarios políticos cuya capacidad estuviese fuera de toda duda. Una decisión que llevaría a Sanín a ocupar cargos de singular importancia durante el Quinquenio Reyes ${ }^{14}$, evidenciando la confianza del presidente en su persona y el compromiso del antioqueño con su valedor.

De entre las lecciones extraídas por Sanín durante sus años con Reyes hubo una que le dejaría particularmente huella: la cuestión de Panamá. En realidad, la separación del Istmo afectó a toda la sociedad colombiana con una crudeza inimaginable, dejando una sensación de fracaso que recorrería el país de un extremo a otro. Reyes ya había sido testigo directo de anteriores injerencias estadounidenses en la región, sobre todo durante la guerra civil de 1885 cuando, tras el incendio de Colón y la insurrección de la guarnición de Buenaventura, la presencia militar norteamericana amenazó con hacerse permanente ${ }^{15}$. No obstante, su experiencia todavía se vería engrosada por los sinsabores vividos, una vez consumada la secesión panameña, como jefe de

13 Luis María Mora llegaría a calificarlo, allá por 1936, como «un radical de cuarzo de los años 50». Y el propio Sanín, en 1951, seguiría definiéndose como liberal por considerar que no se había «encontrado todavía ningún sistema que remplace la voluntad de las mayorías para determinar la forma de gobierno según las normas representadas». Mora, 1936: 138. Triviño Anzola, 1998: 142.

14 Entre 1904 y 1909. En ese periodo no solo ejerció cargos dentro del ejecutivo, donde llegaría a desempeñar la Secretaría de Hacienda o a encargarse de la secretaría del presidente, sino que también ocupó otros puestos políticamente relevantes como la membresía en la Asamblea Nacional Constituyente de 1905, encargada de reformar la Constitución conservadora de 1886.

15 El Tratado Mallarino-Bidlack (1846) había rubricado el compromiso de los Estados Unidos a garantizar la neutralidad del istmo, así como los derechos de soberanía y propiedad neogranadinos sobre el territorio. Fue así que el levantamiento liberal de 1885 justificó la ocupación norteamericana de la región y el establecimiento de guarniciones en Panamá y Colón. No obstante, el temor del gobierno colombiano a que la presencia militar estadounidense se dilatase más de lo debido hizo que se enviase, por vía de urgencia, un contingente 
la delegación colombiana encargada de las negociaciones con Washington; o, ya como presidente, como responsable máximo en la ingrata labor de normalizar relaciones con el nuevo Estado panameño y su protector.

Este mal trago ya lo auguraría el mandatario al asumir el cargo, plasmando en su discurso inaugural el nuevo tiempo abierto dentro del concierto internacional y su carácter intervencionista:

Sabido es que en los últimos tiempos las grandes potencias han proclamado como doctrina y puesto en práctica la intervención en la vida interior de las naciones débiles para obligarlas á conservar el orden y la paz, y dar protección á los intereses industriales extranjeros que en ellas se vinculan; y bien sabido es que esta práctica, contraria al derecho ha sido proclamada especialmente con relación a los países intertropicales de América, que así vienen á quedar sometidos á doctrinas jurídicas que implican respecto á estos países el reconocimiento de un estado político y social inferior á áquél [sic] en que anteriormente eran reconocidos. Como á pueblo de inferior civilización se nos calificó generalmente cuando, por obra de la perfidia, ayudada por el desconcierto y la anarquía á que hemos llegado, fuimos despojados del Istmo de Panamá, y el atentado no solamente fue aprobado y consentido, sino también considerado trascendental servicio hecho á la obra de la civilización universal ${ }^{16}$.

No puede decirse que la reflexión de Reyes fuese original, sino una mera constatación de lo que apuntaba a ser una dinámica internacional consolidada. El propio Sanín insistiría al respecto, poco tiempo después, en un artículo publicado en la barcelonesa Hojas Selectas, refiriendo la toma de Finlandia por Rusia y de Corea por el Japón como una prueba más de la imposición del imperialismo como nuevo dogma geopolítico ${ }^{17}$. Con todo, los acontecimientos asiáticos y europeos eran notas de una sinfonía que, en América, ya llevaba sonando un tiempo, siendo Theodore Roosevelt uno de sus principales instrumentistas.

La presencia de Roosevelt entre las bambalinas de la crisis panameña era, más que un rumor, una sospecha asentada en los medios internacionales. Inspirador de la Doctrina del Big Stick o Diplomacia del Garrote, el nortea-

militar al mando de Reyes, quien confirmaría a Sanín cuán acertadas eran las sospechas del ejecutivo de Bogotá. Sanín Cano, 1909: 206-211.

16 Sanín Cano, 1909: 27.

17 «Todo lo cual significa que el mundo acepta, ó á lo menos los países fuertes dan por aceptado, que el imperialismo es un rumbo de la vida política y que es preciso conformarse con las soluciones que de cuando en cuando impone esa tendencia. Egipto, Panamá, Herzegovina, Finlandia, Corea son el principio de una triste orientación. El siglo XX parece marcar rumbo á esta clase de soluciones». Baldomero Sanín Cano, "Dos pueblos absorbidos: Finlandia y el Imperio de Corea”, Hojas Selectas, n. ${ }^{\circ}$ 106, octubre 1910, 947-948. Accesible online. 
mericano había adquirido una imagen de hombre fuerte en su país en la que combinaría un fuerte sentimiento nacionalista con un populismo jalonado de propuestas reformistas que le granjearían un amplio apoyo en los sectores populares ${ }^{18}$. Ambos aspectos serían muy criticados por un Sanín que despreciaría de igual modo tanto su escasa enjundia ideológica como su doble moral, rechazando de plano, por irreales, los principios alardeados por el norteamericano como fundamentos de su política: la honestidad y la decencia.

Veamos de qué está formado su bagaje ideológico. No, al decir ideológico, creo haber pasado la línea de lo verosímil. Ideas, propiamente, no tiene el Sr. Roosevelt. La temperatura cerebral que ellas requieren para nacer y desarrollarse, fundiría la materia gris de este bello caso de salud intelectual, como diría Max Nordau, el filósofo de Degeneración [...] Pero, en fin, el Sr. Roosevelt tiene principios, ó dice que los tiene, y sus sentimientos constan en el resumen de los discursos políticos que da la prensa diaria. Sobre dos palabras gira ordinariamente el mecanismo sencillo de su complexión intelectual. Honesty y decency reaparecen en el texto de sus quejumbres contra la moderna corrupción social [...]

La honradez del Sr. Roosevelt es la del mercader, cuya sublime aspiración es comprar por uno y vender por tres, si hay quien se decida a pagar este último precio. Es la honradez del calculador estrecho; es la noción moral desvirtuada por largos años de estar dividida la sociedad en dos clases: una que explota, y otra que es explotada. El Sr. Roosevelt encuentra detestable que los grandes sindicatos americanos abusen de su fuerza financiera para desposeer al comerciante al por menor, pero no halla contrario á la honradez política el que una nación poderosa lleve á cabo por razones de comercio, la desmembración de un país indefenso. Otro tanto pudiera decirse de su concepto sobre el alcance de la palabra decencia ${ }^{19}$.

El desprecio de Sanín estaría en consonancia con el manifestado desde el hispanoamericanismo contra el pragmatismo yanqui. Un desprecio que, si en el caso de este movimiento se centraba en el temor a la expansión del materialismo estadounidense en detrimento de los «principios tradicionales hispanos», en el de Sanín cobraría un matiz personal a cuenta de la desmembración del Istmo. En todo caso, la aproximación del antioqueño al hispanoamericanismo y sus zozobras ya se había producido antes de la secesión panameña, quedando de relieve en un artículo publicado en 1902 en la madrileña Nuestro Tiempo. Su título, "Papel de la literatura en la fraternidad hispanoamericana", advertía un trasfondo de acercamiento muy propio del hispanoamericanismo, pero sin que

18 No en vano Roosevelt es considerado una influencia clave en la versión moderna del populismo democrático norteamericano. Es aconsejable, a este respecto, la lectura de The Bully Pulpit: Theodore Roosevelt, William Howard Taft, and the Golden Age of Journalism, de Doris Kearns Goodwin.

19 Baldomero Sanín Cano, "Nueva campaña de Mr. Teodoro Roosevelt", Hojas Selectas, n. ${ }^{\circ} 108$, diciembre 1910, 1132. Accesible online. 
de ello pudiera deducirse un plegamiento absoluto a sus preceptos. Es más, el texto rebatiría no pocos convencionalismos del movimiento como la Raza - aun dándole un sesgo fenotípico que parcializaría el concepto - o la recurrente «comunidad de aspiraciones» que, en verdad, no dejaba de ser una leyenda. Sin embargo, Sanín también haría patente el propósito reivindicativo de lo hispanoamericano en su rechazo, sin paliativos, de las supuestas virtudes desarrollistas argüidas por las grandes potencias para postularse a tutelar territorios ajenos, siendo la unificación iberoamericana una respuesta plausible a tales pretensiones y la lengua la plataforma -única, a su parecer- sobre la que construirla:

Los que desean la unificación de los pueblos ibero-americanos no tienen sus anhelos puestos en un imposible. Solamente un lazo nos queda, que es la lengua. Lazo vivo, tan fuerte y duradero, que él solo basta para fundar la fraternidad de los pueblos, en tanto que á ella no se opongan significativos intereses o sentimientos vivamente arraigados. Esta bendición de un idioma que oye uno hablar con uniformidad [...] en casi todo un continente, sin interrupciones y con levísimos cambios que no alteran la índole, es fenómeno de que importa sacar provecho. El error de Asociaciones ibero-americanas, de los Ateneos y demás florescencias efímeras que por acá hemos visto pasar y marchitarse, nace de que, sin desconocer el valor de la lengua como elemento de fraternidad, quisieron también apoyarse en la política, tomar consejo de una diplomacia inepta, adularles á los gobiernos, por todo lo cual $\mathrm{y}$, con beneplácito de muchos, murieron casi sin haber vivido ${ }^{20}$.

Las observaciones de Sanín respecto al papel desarrollado por el asociacionismo hispanoamericanista resaltarían la necesidad de buscar puntos de encuentro que no levantasen controversias entre los países iberoamericanos, de ahí el apunte a no oponer «significativos intereses o sentimientos vivamente arraigados» entre los mismos e incidir en el elemento que, en su opinión, menos controversias podía despertar: la lengua.

El factor lingüístico, motivo de litigio durante décadas ${ }^{21}$, se convirtió en un punto de acercamiento entre los países hispanohablantes desde el momen-

20 Baldomero Sanín Cano, "Papel de la literatura en la fraternidad hispanoamericana", Nuestro Tiempo, n. ${ }^{\circ}$ 14, febrero 1902, 217-218. Accesible online.

21 No solo entre España y las repúblicas hispanoamericanas sino, incluso, dentro de estas. Tras las independencias no fue infrecuente, en los procesos americanos de construcción nacional, polémicas entre los grupos de poder respecto al papel a desempeñar por una lengua, el español, heredada de la metrópoli a la que se había expulsado. Fue así que hubo grupos que quisieron reivindicar el "español" como lengua propia, americana, desechando la supuesta privatividad que pudiera arrogarse la Península. Otros, en su afán por reivindicar la propia idiosincrasia, buscaron remarcar los particularismos a fin de distinguirse del resto y, sobre todo, de España. Una buena expresión de lo dicho, trasladada al caso argentino, podemos encontrarla en Sepúlveda, 2005: 212-213. 
to en que la Real Academia de la Lengua rompió el monopolio español introduciendo académicos americanos en su seno y aceptando la fundación de instituciones similares en el continente ${ }^{22}$. No es que con ello las disputas sobre la lengua desapareciesen, pero sí cambió el sentido de las mismas. Durante décadas los sectores más conservadores de la intelectualidad española habían sido refractarios a reconocer autoridad alguna a los países hispanoamericanos para discernir sobre la cuestión lingüística. La decisión de la Academia supuso un paso importante en pos de solventar tales diferencias, si bien las disputas pasaron de girar en torno a la legitimidad americana para opinar sobre el idioma a hacerlo sobre lo que este debía ser, siendo manifiesto el temor y la crítica de los entendidos a la contaminación de la lengua con «corrupciones foráneas» - entendiendo como tales las procedentes de otros idiomas- pero también la oposición de muchos de ellos a incluir palabras, vocablos y giros ajenos de origen americano ${ }^{23}$.

Las disputas en torno al español, como idioma, no impidieron que este cobrase un carácter multinacional, pero con un añadido trascendente a corto y medio plazo ya que, conforme el expansionismo estadounidense fue despojándose de disimulos, la lengua acabaría convirtiéndose en símbolo, reivindicación y fuente de resistencia de los países hispanohablantes. Es ahí donde la apuesta integradora de Sanín cobraría mayor sentido, al secundar la vinculación iberoamericana a través del idioma en contraposición a las ambiciones europeas y norteamericanas.

La reivindicación de la lengua como germen de identidad hunde sus raíces en el idealismo teutón, siendo uno de los pilares del pangermanismo. Empero la máxima, igual que serviría para fundamentar los distintos proyectos surgidos de la cuestión alemana ${ }^{24}$, también valdría para un hispanoamericanismo

${ }^{22}$ Como bien señala Sepúlveda, para 1866 la RAE ya contaba con seis académicos americanos, fundándose antes de fin de siglo sus correspondientes en Colombia, Ecuador, México, El Salvador, Venezuela, Chile y Perú. Sepúlveda, 2005: 69.

23 Sanín fue uno de los críticos a la cerrazón de aquellos sectores peninsulares reacios a cualquier apertura. Otros serían, por citar algunos, el guatemalteco Antonio Batrés o, incluso, un joven Borges que, ya bien entrado el siglo XX, despuntaría por su defensa del criollismo desde una perspectiva vanguardista y alejada del mero localismo. Es recomendable para conocer más detalladamente el tema, la lectura de "La intelectualidad conservadora mexicana y Marcelino Menéndez Pelayo. Impresiones de una relación a finales del siglo XIX y principios del XX", de Ricardo Pérez Monfort, 2010, así como el trabajo de Aimer Granados "Imaginarios culturales sobre España en la celebración del centenario de la independencia de Colombia", editado en la obra coordinada por Tomás Pérez Vejo Enemigos íntimos. España, lo español y los españoles en la configuración nacional hispanoamericana, 1810-1910.

24 Nos referimos a la Großdeutsche Lösung impulsada desde Viena y que buscaba la unificación de todos los pueblos germanófonos bajo un solo Estado; y el Kleindeutsche Lö- 
siempre constreñido de cimientos sobre los que elevar su propio sentido colectivo. Un ejemplo habitual a la hora de aludir la vindicación hispanoamericanista del idioma es Unamuno, referente de la generación noventayochista que, en un conocido artículo publicado en La Vida Literaria, glosaría el carácter metahistórico de la lengua como base del espíritu de los pueblos:

La lengua es, en efecto, la raza del espíritu [...] La lengua, sedimento vivo de la labor de la historia; tradición viva del pueblo; concentrado depósito, á presión de atmósferas seculares, de los trabajos del espíritu; la lengua es la base de la continuidad, en espacio y tiempo, de los pueblos, y es, á la vez, el alma de su alma 25 .

Tal aserto, compartido por Sanín ${ }^{26}$, cobraría una especial relevancia en el contexto de crisis en el que se movería España tras el Desastre del 98, actuando como puente entre una exmetrópoli predispuesta a vindicar la defensa de los valores culturales hispanos por encima, incluso, de cualquier interés comercial o económico ${ }^{27}$, y unas repúblicas americanas a las que la idea de comunidad cultural les serviría para armar un discurso en el que la fraternidad de sus miembros apuntalaría la rebeldía frente a la legitimación intervencionista perpetrada por el Corolario Roosevelt.

Si una nación demuestra que sabe actuar con una eficacia razonable y con el sentido de las conveniencias en materia social y política, si mantiene el orden y respeta sus obligaciones, no tiene por qué temer una intervención de los Estados Unidos. La injusticia crónica o la impotencia que resultan de un relajamiento general de las reglas de una sociedad civilizada pueden exigir, a fin de cuentas, en América o fuera de ella, la intervención de una nación civilizada y, en el hemisferio occidental, la adhesión de los Estados Unidos a la Doctrina Monroe puede obligar a los Estados Unidos, aunque en contra de sus deseos, en casos flagrantes de injusticia o de impotencia, a ejercer un poder de policía internacional28.

sung, planteado por Prusia y que dejaría fuera de su proyecto unificador, precisamente, a su adversario austriaco.

25 Miguel de Unamuno. "The English-Speaking Folk", La Vida Literaria, n. ${ }^{\circ}$ 10, 11 de marzo de 1899, 2. Accesible online.

${ }^{26} \mathrm{Al}$ punto de describir el idioma como «uno de los testigos y pilotos que hemos de consultar al tratar de escudriñar el pasado remoto de las naciones; y para ponernos en contactos con su alma, y sentir las palpitaciones de su vida». Baldomero Sanín Cano. "La lengua internacional", Nuestro Tiempo, n. ${ }^{\circ}$ 39, marzo 1904, 357. Accesible online.

27 Entre otros motivos, por su incapacidad para liderar proyectos de integración más ambiciosos en el ámbito político, económico o comercial. Andrés García, 2014: 607.

28 Theodore Roosevelt, "State of the Union Message. December 6, 1904", Almanac of Theodore Roosevelt (19/03/2018), URL: http://www.theodore-roosevelt.com/images/research/ speeches/sotu4.pdf. La traducción es personal. 
Sanín redobló sus contactos con autores españoles tras la caída del gobierno Reyes. Trasladado a Londres poco tiempo antes de la dimisión presidencial, fue tras perder la confianza del nuevo ejecutivo que el antioqueño retornaría al periodismo, complementando su sustento con otras labores como dar clases particulares de español. Su desencuentro con el gobierno finalizaría en 1911, año en el que sería designado cónsul en la capital británica ${ }^{29}$, empero tal nombramiento no le supuso el abandono de la actividad periodística; un trabajo que, además de darle grandes satisfacciones, también le proveería de una nutrida y variada red de contactos. Fue en ese periplo que comenzó sus colaboraciones con la revista Hispania, fundada por Santiago Pérez Triana y que contaría entre sus aportes con firmas como las de Unamuno, Pérez de Ayala, Ramiro de Maeztu, José Ingenieros y la de un Luis Araquistáin que sería determinante, posteriormente, durante su estancia española ${ }^{30}$. Del mismo modo, también trabaría contacto con un Leopoldo Lugones que lo embarcaría, como colaborador, en La Revue Sud-Américaine, publicación en la que ejercía como director y en la que reservaría al colombiano una sección fija: "La Sud-Amérique á Londres" 31 .

Los años londinenses supusieron para Sanín la apertura de nuevas perspectivas y temáticas, así como el reconocimiento en foros ajenos a los de su Colombia natal. Cierto es que su bagaje político y diplomático tendrían un peso considerable en sus análisis, pero tampoco puede desdeñarse la peculiar riqueza de sus crónicas, aliñadas con reflexiones que, en sus matices, darían cabida, de igual modo, tanto a su convencimiento sobre la esencia española del alma americana ${ }^{32}$ como a su implacable juicio sobre la malsana celebridad de Roosevelt y su exigua lucidez:

\section{Sanín Cano, 1978: 387.}

30 No merece la pena incidir en lo que fue la colaboración de Sanín con dicha publicación por haber sido sobradamente tratado por Gómez y Rubiano, 2016.

31 Carilla, 1974: 517.

32 Visible en el intercambio de pareceres entre el escritor y Unamuno a raíz de un artículo del primero publicado en Hispania en junio de 1913, "La Race Incomprise (Sobre España)", y que Sanín concluiría con las siguientes palabras: «El día en que España dejara de existir, no sólo políticamente, sino también desde el punto de vista étnico [...] quedaría del otro lado del Atlántico el alma española casi en su integridad. Si a más de desaparecer España como entidad étnica y política, desapareciera también en Europa la cultura que ella representa, podría reconstruirse todo el significado ético y científico de esa cultura estudiando los pueblos americanos, así como sería posible reconstruir el latín, si llegara a desaparecer, estudiando las siete u ocho lenguas que de él se han derivado». Baldomero Sanín Cano, "Respuesta a Unamuno"; en Hispania, $1^{\circ}$ de julio de 1913. El intercambio de escritos entre ambos autores aparece plasmado en Sanín Cano, 1978: 164-172. 
El coronel Teodoro Roosevelt es un exponente de su tiempo. Nació para vivir en el siglo XX la vida inquieta, superficial y malsana del periodista entregado a la política. Nació para llevar el estrago allí donde la civilización no ha penetrado con sus herramientas igualitarias. Un día hace la guerra en Cuba. Otro madruga a preparar en Washington una revolución sud-americana. Gobierna un Estado, gobierna una nación, y se figura por eso que es árbitro de un continente [...]

Importa dejar constancia de uno de sus modos de razonar [...] el señor Roosevelt sintió una gran sorpresa al ver a un armadillo huyendo del hombre en carrera vigorosa por la selva amazónica. Y decía el coronel Roosevelt: ¿Cómo es posible que un animal de concha como la tortuga pueda correr con esta velocidad? En otras palabras, el coronel razona de este modo: la tortuga tiene concha; la tortuga anda lentamente; luego la concha y la lentitud son cualidades inseparables.

Este razonamiento nos da el calibre de su inteligencia ${ }^{33}$.

Hispania no se editó más allá de 1916, pero a Sanín no le faltarían ofertas tras su clausura. La más interesante le llegaría en 1918 de la mano de $L a$ Nación de Buenos Aires, comenzando con la corresponsalía en Londres una relación profesional con el diario porteño que se extendería hasta 1931 y que, en 1922, le llevaría a España para hacerse cargo de su delegación en Madrid ${ }^{34}$.

\section{SANÍN EN MADRID. LA REIVINDICACIÓN DE AMÉRICA Y EL HISPANOAMERICANISMO EN UN CONTEXTO DE POSGUERRA. UNA PROPUESTA DE CONGRESO}

De entre los contactos que trabó Sanín durante su periplo londinense hubo uno que sería particularmente importante en lo concerniente a su estancia en España: Luis Araquistáin.

Araquistáin, miembro de la Generación del 14 y también colaborador de la revista Hispania, trabaría un aprecio intelectual con el colombiano perceptible en la reseña que este último haría de su primer libro: Polémica de la Guerra: 1914-1915. En ella, Sanín realzaría la figura del vasco como la de un pensador que aunaba una escritura excelente, un pensamiento sólido, una escrupulosa precisión conceptual y «una vena humorística de la mejor calidad [...] que se reserva para las ocasiones más altas y trascendentales $»^{35}$.

33 Baldomero Sanín Cano, "El coronel Teodoro Roosevelt", Hispania, 1º de julio de 1914. Extraído de Sanín Cano, 1978: 172-175. 2013.

${ }^{34}$ Sobre Sanín y su experiencia en La Nación es aconsejable la lectura de Rubiano Muñoz,

35 Baldomero Sanín Cano, "El primer libro de Araquistáin: Polémica de la Guerra", Hispania, 47 y 48, 1 de diciembre de 1915, pp. 1480-1481. Extraído de Gómez García y Rubiano Muñoz, 2016: 266-269. 
Militante socialista desde 1911, Araquistáin tenía asumida como propia la preocupación hispanoamericana por el expansionismo estadounidense, probablemente por haber tomado conciencia de la misma tras vivir en Argentina entre 1904 y 1908. Sus inquietudes a este respecto quedarían expuestas en $\mathrm{El}$ peligro yanqui, escrito tras viajar a Washington, en octubre de 1919, para asistir a la Conferencia Internacional del Trabajo como delegado de la Unión General de Trabajadores (UGT) junto a Largo Caballero y Fernando de los Ríos. En el preámbulo del ensayo, publicado en 1921, Araquistáin manifestaría su temor a una política armamentística - la de Estados Unidos y otros como Gran Bretaña o Japón- equiparable a la que había empujado al mundo a la guerra apenas dos años antes. Empero su posicionamiento antiimperialista vendría de la mano de una colectivización del problema como causa española e hispanoamericana, concienciando a los lectores desde unos parámetros tan cercanos a Sanín como al hispanoamericanismo:

El peligro yanqui, además, lo es especialmente para el resto de América. El capitalismo norteamericano puede ser espuela de progreso para las Repúblicas rezagadas de América; pero tras el capital van la bandera, los ejércitos, las instituciones, la lengua, la cultura del pueblo invasor. Admiramos vivamente la cultura anglosajona; ha sido nuestro mayor sustento espiritual; pero la aborreceríamos si quisiera imponérsenos, descuajando la personalidad histórica de nuestro país. Y en cierto modo, cada país americano de lengua española es una continuación, a veces superada, del nuestro. A España no puede serle indiferente el futuro de la América de su lengua. Extinguido felizmente el imperio de la materia, queda un imperio ideal, de tipo hispánico y fines culturales entre Europa y América. Este imperio del espíritu es el que nos duele ver amenazado por el peligro yanqui. No nos dolió la pérdida de las Antillas; antes bien, nos pareció una ley del tiempo y una sanción histórica a nuestros desaciertos. Pero nos aflige que un portorriqueño, por ejemplo, hable el español como un norteamericano. Contra este peligro específico hemos de estar prevenidos españoles e hispanoamericanos ${ }^{36}$.

Araquistáin se labraría un gran prestigio como director de la revista Espa$\tilde{n} a$, fundada en 1915 por Ortega y Gasset y, sin duda, una de las publicaciones más señeras de su tiempo por su estrecha vinculación con las corrientes neorregeneracionistas. La pluralidad del semanario, dentro de su naturaleza reformista y crítica, haría que entre sus colaboradores se contasen intelectuales de ideología variada pero, en todo caso, descontentos con un régimen, el de la Restauración, en plena crisis política, social y económica. Ramón Pérez de Ayala, Luis de Zuloaga, Ramiro de Maeztu, Eugenio d'Ors, Ortega, Pío Baroja, Enrique Díez-Canedo... se contaron entre sus primeros redactores, pu-

36 Araquistáin, 1921: 2. 
diendo encontrar posteriormente en sus páginas aportes de, entre muchos otros, Unamuno, Benavente, Valle Inclán, Juan Ramón Jiménez, Azorín o Manuel Azaña, quien sería su tercer y último director.

Sanín pasó a colaborar con la revista en julio de 1919, siendo anunciado como «uno de los escritores críticos, del tipo ensayista, más cultos, elegantes y sagaces de América» ${ }^{37}$. No era, en todo caso, un desconocido para sus colegas de publicación, habiendo coincidido con algunos de ellos - como Unamuno, Pérez de Ayala, Azorín o Ramiro de Maeztu - en la Hispania de Pérez Triana ${ }^{38}$. Del mismo modo, la erudición y elegancia de sus aportaciones ratificarían, de cara al público, los halagos vertidos en su presentación, ya fuese disertando sobre el humor y la sentimentalidad ${ }^{39}$; refiriendo los imprevisibles estragos de las fabulaciones ${ }^{40}$; o evocando la obra poética de Giosuè Carducci (1835-1907) para advertir sobre los peligros del fascismo y la censura ${ }^{41}$.

Un ambiente diplomático tan complejo como el de entreguerras hizo que las opiniones de Sanín no pasasen desapercibidas, evidenciándose en episodios como la firma del Pacto de la Sociedad de Naciones, al que España se adhirió, en palabras del colombiano, «irreflexivamente y sin reservas» ${ }^{42}$ frente a la más que comprensible cautela de las repúblicas hispanoamericanas.

La controversia devino a cuenta del articulado y, sobre todo, por el reconocimiento implícito de la Doctrina Monroe dentro del mismo ${ }^{43}$. Partiendo de tal supuesto, la nueva organización desvirtuaba la supuesta equidad entre los Estados miembros pero, sobre todo, desnaturalizaba uno de sus principales propósitos: evitar toda conflagración que pudiera atentar contra la integridad

37 Baldomero Sanín Cano, "La aurora de un mundo nuevo - Nostalgia del campamento", España, n. ${ }^{\circ}$ 223, 17 de julio de 1919, pp. 6-8. Accesible online.

38 Gómez García y Rubiano Muñoz, 2016: 68.

39 Baldomero Sanín Cano, "Un humorista sudamericano", España, n. o 359, 3 de marzo de 1923, pp. 4-5. Accesible online.

40 Baldomero Sanín Cano, "Justicia Rerum", España, n. o 235, 9 de octubre de 1919, pp. 8-9. Accesible online.

41 Baldomero Sanín Cano, "Un bardo político y la Ley de Prensa", España, n. o 403, 5 de enero de 1924, pp. 5-8. Accesible online.

42 "Reservas a Monroe", España, n. ${ }^{\circ}$ 260, 24 de abril de 1920, p. 9. Accesible online.

43 Concretamente en el artículo 21: «Los compromisos internacionales, tales como el tratado de arbitraje, y las inteligencias regionales, (ententes regionales), como la doctrina de Monroe, que aseguran el mantenimiento de la paz, no se consideran incompatibles con ninguna de las disposiciones del presente pacto". "Pacto de la Sociedad de Naciones, firmado en Versalles el 28 de junio de 1919", Universidad Carlos III OpenCourseWare. Accesible online. 
territorial o la independencia política de los firmantes ${ }^{44}$. La contradicción sería tan manifiesta como ajustada a las ambiciones norteamericanas, de ahí que el semanario recogiese las reflexiones de Sanín en el Manchester Guardián $\mathrm{y}$, sobre todo, la apreciación que haría de tal cesión: una carta blanca concedida a los Estados Unidos en América para mantener su supremacía al margen de la voluntad de sus vecinos. Después de todo, como indicaría el bogotano echando la mirada atrás:

... los Estados sudamericanos no tienen que temer el ser conquistados unos por otros. Este caso sólo se ha presentado una vez, mientras que los Estados Unidos «en el provechoso campo de la doctrina de Monroe» tienen en su cuenta: Méjico, Puerto Rico, Colombia, Santo Domingo y Haitit ${ }^{45}$.

La subsidiariedad de los países hispanoamericanos en el concierto internacional todavía se haría más patente a comienzos de 1922, al no ser invitado ninguno de ellos a la Conferencia de Génova. La reunión, convocada por la Sociedad de Naciones, no era precisamente baladí, ya que respondía a la necesidad de tomar medidas con las que reconstruir el comercio y el sistema financiero internacional, severamente dañados tras la Gran Guerra. Pese a que muchas de las decisiones irían dirigidas a reactivar la economía europea, muy alejada de su tradicional prosperidad, de lo que nadie tenía duda era de que los acuerdos que se consensuasen acabarían afectando a toda la economía mundial, de ahí que para Sanín resultase inverosímil la ausencia de los países latinoamericanos:

¿Presumen los individuos reunidos en aquel puerto del Mediterráneo que se pueden regularizar los cambios y restituir el comercio a sus antiguas veredas sin el concurso de los setenta u ochenta millones de hombres que ocupan la región hispanolusa del continente americano y de las islas adyacentes?

A aquellos países no podrá imponérseles un patrón monetario contra su voluntad. Además, sería una enorme iniquidad señalar un tipo de cambio con una unidad monetaria internacional sin el concurso de los pueblos que deben ingentes sumas a algunas de las potencias reunidas en Génova. Sería el primer caso en que un acreedor se arrogara el derecho de señalarle al deudor, no vencido en guerra, la obligación de pagar en una especie distinta a la convenida ${ }^{46}$.

44 Tal y como indicaba el artículo 10 del texto: «Los miembros de la sociedad se comprometen a respetar y mantener contra toda agresión exterior la integridad territorial y la independencia política presente de todos los miembros de la sociedad. En caso de agresión, de amenaza o de peligro de agresión, el consejo emitirá opinión sobre los medios de asegurar la ejecución de esta obligación». Ibidem.

45 "Reservas a Monroe", España, n. ${ }^{\circ}$ 260, 24 de abril de 1920, p. 9. Accesible online.

46 Baldomero Sanín Cano, "Opiniones Americanas - La ausencia de América en Génova”, El Sol, n. ${ }^{\circ}$ 1466, 20 de abril de 1922, p. 1. Accesible online. 
El ensayista no ignoraba la posición de fuerza en que había quedado Estados Unidos tras la Primera Guerra Mundial. Si decisiva había sido su intervención en el conflicto, determinante era su opinión en la posguerra, si bien sus intereses chocarían en no pocos asuntos con un panorama europeo sumamente complejo. En todo caso, las deudas contraídas por los vencedores con el Coloso norteamericano conferirían a este prerrogativas que, de otro modo, difícilmente habría disfrutado. Una ya fue visible en el Pacto de la Sociedad de Naciones; otra, al parecer de Sanín, se estaba produciendo en esos momentos en Génova:

Por último, no es de creer que Francia y la Gran Bretaña consideren deseable para sus ideales e intereses la hegemonía moral y política de los Estados Unidos en el Nuevo Mundo. La vituperable complicidad o indiferencia de que es prueba la exclusión de la América española, acaso se inspire en las consideraciones del deudor que espera ver cancelada su deuda en un momento de generosidad. Tal actitud es explicable; pero pugna con las tradiciones de Francia y con la magnitud de los intereses que Inglaterra ha creado y mantiene al sur del Río Grande ${ }^{47}$.

La marginación latinoamericana en estas reuniones, unida a los frustrantes resultados de las mismas, llevaría a Sanín a proponer la celebración de un Congreso hispanoamericano. Fue en las páginas de El Sol y la iniciativa suscitó reacciones de distinto signo en la prensa local. Los argumentos para convocar tal evento eran de difícil refutación: la Conferencia de París, celebrada cuatro años antes, había supuesto un desastre para los derrotados, pero, paradójicamente, también deslizó la disensión entre los vencedores. Las discordancias serían tan tangibles que todos los buenos deseos de paz enunciados tras el armisticio se vieron ahogados por los intereses de parte ${ }^{48}$. Un problema que vendría a enquistarse, visto el desinterés de los implicados por cualquier intermediación $\mathrm{o}$, incluso, por escuchar opiniones ajenas a las presentes en estos foros:

Más de veinte Conferencias se han celebrado para resolver los problemas creados por el advenimiento de la paz. La inanidad del resultado, en la mayor parte de los casos, bien sabemos a qué atribuirla: al conflicto de apetitos entre las naciones representadas en esas Conferencias y al influjo de los intereses de partido en la solución de cuestiones característicamente universales. Los asuntos que allí

47 Ibidem.

48 Y no eran pocos a la vista de los temas espinosos que desgranaría Sanín en su escrito, empezando por la redistribución de África; el control del petróleo persa e iraquí; la cuestión de las reparaciones de guerra; los distintos posicionamientos respecto a Rusia... En Baldomero Sanín Cano, "Iniciativa interesante - Motivo para un Congreso hispanoamericano", El Sol, n. ${ }^{\circ} 1692,11$ de enero de 1923, p. 1 . Accesible online. 
se debaten no afectan solamente a la vida y al porvenir de las naciones aliadas. Tienen alcance mundial [...] Sin embargo, de algún tiempo a esta parte, y sistemáticamente, se hace caso omiso en estas juntas internacionales de muchos países cuyos intereses están ligados a la solución de las cuestiones pendientes entre los aliados y sus antiguos adversarios ${ }^{49}$.

Fue precisamente esta omisión la que justificaría su propuesta. Ausente la América Hispana en estas citas y afectada sin remedio por sus conclusiones, la prudencia aconsejaba adelantarse a las previsibles secuelas de los desencuentros europeos, al igual que medir el grado de cercanía existente entre los países hispanoamericanos y la propia España:

En esta situación, no habría daño en que España y las Repúblicas americanas se reuniesen a deliberar. No es cordura, con la experiencia y el remordimiento tan recientes, esperar a que la gran desgracia, la enorme catástrofe, nos encuentre de nuevo desprevenidos [...] Además, ha llegado la ocasión de sondear el alma de la raza. ¿Arrancan del fondo del alma colectiva de esos pueblos los decantados sentimientos de solidaridad? ¿Existe, en verdad, un anhelo de acercamiento? El Congreso vendría a sellar estas aspiraciones con la sanción del hecho ${ }^{50}$.

La idea de Sanín apuntaba un potencial que se haría notar en el editorial de ese mismo número, al igual que los riesgos de la misma. Las ventajas de un acercamiento entre los países de habla hispana - y más en un momento de inestabilidad política y económica como el que se vivía - estaba fuera de toda discusión. No obstante, las dudas se suscitaban en cuanto a la naturaleza de tal aproximación, es decir, los asuntos a discutir y los objetivos a concertar. Una duda comprensible teniendo en cuenta la falta de concreción material a que España y el hispanoamericanismo solían abocar este tipo de actos:

Si en el momento de una crisis mundial, España y América no establecen la comunicación deseada, lo más probable es que nunca lleguen a mayor proximidad que la presente [...] Ahora bien; los grandes anhelos, siempre un poco abstractos y vagos, no alcanzan la realidad si no descienden a puntos muy concretos y definidos; por esta razón no bastará la iniciativa del llamamiento si las naciones apeladas no detallan antes con toda precisión los asuntos que precisan deliberación y acuerdo. No vamos a reunirnos sin más materia de reunión que la de un sentimiento de raza; para aumentar su compenetración, los pueblos necesitan asuntos comunes de vida o muerte ${ }^{51}$.

49 Ibidem.

50 Ibidem.

51 "Idea de una Conferencia iberoamericana", El Sol, n. ${ }^{\circ}$ 1692, 11 de enero de 1923, p. 5. Accesible online. 
El editorial conminaría a extender la invitación, por motivos obvios, a Portugal y Brasil. Una idea secundada en La Libertad por Augusto Barcia ${ }^{52}$, quien afinaría más los criterios sobre los que podría moverse la futura reunión hispanoamericana, enfocándola en la misma dirección que la Convención de La Haya de 1907, es decir, en pos de apuntalar activamente el sistema jurídico internacional impulsado por la Sociedad de Naciones para la resolución pacífica de los conflictos.

España, histórica, geográfica, política, económicamente, tiene lazos indisolubles con Europa. Nada puede ni debe hacer que tienda a debilitarlos [...]

Pero étnica y espiritualmente, España, como Portugal, tiene sus vínculos más recios con América. Y todas las naciones del Nuevo Continente, de nuestra habla [...] cada día va afirmando más su tendencia a buscar garantías de justicia internacional $[\ldots]$ en forma arbitral, creando grandes tribunales, prestigiosos organismos que con su autoridad moral brinden soluciones pacíficas para todos los conflictos de la política exterior.

Hoy existe, aunque en estado germinal [...] ese gran instrumento de paz que se llama la Sociedad de Naciones. Si todos los países de América, con Portugal y España, se concertasen para llevar al seno de ese supremo tribunal los magnos problemas internacionales, invitando, con su carácter de neutrales, a comparecer ante él a los países litigantes, se daría un paso decisivo en el camino de la pacificación moral y material del mundo y de la reconstitución de Europa ${ }^{53}$.

Las sugerencias de constituir un frente activo en su neutralidad que procurase acercar posturas y rebajar la tensión internacional tenía sentido, pero escasas posibilidades de realizarse. En cinco años toda benevolencia que pudiera haber existido recién acabada la guerra había desaparecido; y ninguno de los vencedores podía erigirse con autoridad moral suficiente como para ser escuchado por el resto. Baste recordar cómo, en esos mismos días, Francia

52 Una personalidad polifacética como pocas $\mathrm{y}$, sin duda, merecedor de una investigación más detallada. Jurista, político, periodista, conferenciante, profesor... En la II República llegaría a ejercer como ministro de Estado e, incluso, a presidir provisionalmente el Consejo de Ministros tras el nombramiento de Azaña como presidente. A sus méritos profesionales, políticos e intelectuales habría que adjuntarles su condición de alto cargo de la masonería, llegando a ser Gran Maestre del Gran Oriente Español en 1921 y, en 1929, Soberano Gran Comendador del Supremo Consejo del Grado 33 para España y sus dependencias. Queda señalar por último que, pese a ser un europeísta convencido, en sus artículos sobre la problemática internacional y el papel a jugar por España nunca dejó de insistir en la necesidad de fomentar y reforzar los vínculos con la América Hispana. Un acercamiento interesante a su figura es el planteado en el "Museo Virtual de Historia de la Masonería", UNED. Accesible online.

53 Augusto Barcia Trelles, "Deberes de España", La Libertad, n. ${ }^{\circ}$ 972, 12 de enero de 1923, p. 1. Accesible online. 
ocupaba el Ruhr para cobrar por la fuerza las reparaciones de guerra alemanas. Gran Bretaña apenas levantó la voz para protestar, a diferencia de Washington que, como medida de protesta, mandó retirar su ejército del Rin. No obstante, el contrasentido sería manifiesto, ya que Estados Unidos llevaba actuando de un modo similar al francés, en Centroamérica y el Caribe, desde hacía años, tal y como recordaría Luis Araquistáin en respuesta a la proposición de Barcia:

... Estados Unidos pierde toda autoridad cuando se recuerda que ellos han sido maestros de Francia en tales procedimientos con países débiles como Panamá, Nicaragua, Santo Domingo y otros del centro de América. Han ocupado sus Aduanas y mediatizado sus gobiernos con pretextos de obligaciones económicas no cumplidas $^{54}$.

En realidad, tal controversia ya se había planteado veinte años antes con el bloqueo naval a Venezuela. En esa ocasión Gran Bretaña, Alemania e Italia pretendieron cobrar sus deudas al gobierno de Cipriano Castro siguiendo al dedillo las pautas de la Diplomacia del Cañonero. Sorprendentemente Estados Unidos - en su condición de intermediario- fue uno de los grandes beneficiarios del conflicto ya que, si bien garantizó el cobro a las potencias agresoras, también hizo patente a estas su frontal oposición a futuras empresas militares en el continente. Así, los sucesos de Venezuela serían el último capítulo de las intervenciones europeas en América, pero también fueron el detonante de un razonamiento jurídico que, cuatro lustros después, volvía a la palestra: la Doctrina Drago.

Enunciada en 1902 por Luis María Drago, ministro argentino de Relaciones Exteriores, en ella se defendía que ningún país americano pudiera sufrir una agresión exterior para cobrar una deuda financiera. Dicha doctrina fue tomada como base en la Convención de La Haya, cinco años después, para fundamentar el uso del arbitraje como mecanismo con el que solventar los conflictos internacionales sin recurrir a la violencia. Un antecedente marginado que, no por casualidad, Araquistáin recogería para secundar el enfoque de Barcia en caso de que el Congreso se celebrase.

Hubo quien, como Camilo Barcia ${ }^{55}$, consideraría absurdas las invocaciones de Washington a la Doctrina Drago por los sucesos del Ruhr. Sin embargo, el

54 Luis Araquistáin, "La Doctrina Drago y Francia en el Rhur", El Sol, n. ${ }^{\circ}$ 1695, 14 de enero de 1923, p. 1. Accesible online.

55 Probablemente, en el marco del Derecho, uno de los internacionalistas españoles más brillantes de su tiempo. Hermano menor de Augusto Barcia, fue beneficiado en varias ocasiones por la Junta de Ampliación de Estudios, conservándose en su expediente diversos trabajos - como "La significación originaria de la Doctrina de Monroe" o "Ensayo sobre un imperialismo de raza. El pangermanismo"- que indican su propensión temprana al análisis de las 
menor de los Barcia también manifestaría serias dudas respecto a la propuesta de Sanín por la constatable supremacía norteamericana en el continente, de manera tal que un Congreso americano como el bosquejado, sin la presencia de los Estados Unidos, parecía abocado a la esterilidad; y con su presencia, al fracaso:

... ¿puede pensarse en la eficacia de una acción americana en la cual no participen los Estados Unidos? No creemos tampoco que el problema tuviese solución incluyendo a Norte América en ese planeado Congreso, al cual no podía concurrir sin purificarse previamente de su política sojuzgadora de Centro América [...] no apreciamos, por ahora, de qué modo puede procederse a la formación de una acción iberoamericana ni con los Estados Unidos, esclavizadores de Repúblicas americanas, ni contra los Estados Unidos, que representan la mayor fuerza y la más grande eficacia en el Mundo Nuevo ${ }^{56}$.

Esta última opinión estaba muy arraigada en Europa, radicando su raíz, en opinión de Sanín, en la acostumbrada tradición de los estadistas de resaltar la fuerza sobre el derecho. Con todo, en su respuesta a Barcia argüiría dos motivos por los que descartar la presencia de los Estados Unidos en el encuentro: por un lado, el público posicionamiento norteamericano de no interferir «en asuntos internacionales de significación europea» ${ }^{57}$; por otro, su muy probable desinterés por reunirse con unos países hispanoamericanos con los que iba a encontrarse, poco después, en la Cumbre Panamericana de Santiago ${ }^{58}$. A estas razones habría que sumarle una tercera no menos importante: la preeminencia del contexto doméstico en la política de partido, signando las decisiones de ámbito internacional con una inmediatez totalmente contraproducente para los propósitos universalistas del Congreso a convocar.

Barcia reconocería como apropiadas las razones de Sanín, transponiéndolas a la discontinuidad diplomática estadounidense y al aislacionismo intermitente - al menos respecto a Europa - que había caracterizado su actuación internacional. No obstante, los propios acontecimientos parecían indicar que el abstencionismo estadounidense ya no dependía de sí mismo. Entre otros

políticas expansionistas. Para cuando salió el artículo que apuntamos, ocupaba cátedra en la Universidad de Valladolid. Más información en el "Diccionario de Catedráticos Españoles de Derecho (1847-1943)" Instituto Figuerola de Historia y Ciencias Sociales (UC3M). Accesible online.

56 Camilo Barcia, "El cobro coercitivo de las deudas", La Libertad, n. ${ }^{\circ} 976,17$ de enero de1923, p. 1. Accesible online.

57 Baldomero Sanín Cano, "Sobre una iniciativa - El Congreso hispanoamericano", El Sol, n. ${ }^{\circ}$ 1700, 20 de enero de 1923, p. 1. Accesible online.

58 Celebrada como Quinta Conferencia Panamericana del 25 de marzo al 3 de mayo de ese mismo año. 
motivos porque la compleja situación europea aconsejaba una actitud más activa si quería recuperar, de hecho, a los aliados y, a la par, evitar que las exigencias de estos quebrasen toda posibilidad de recuperación económica de los vencidos.

La pregunta que cabía hacerse — conforme a las previsiones de Barciasería cómo iba a afectar ese previsible cambio de actitud de la diplomacia norteamericana a la América Hispana. O, desde otra perspectiva, hasta qué punto ese cambio determinaría el accionar de los países hispanoamericanos. No sin cierta malicia, el periodista indicaría cómo esa conjunción ya podía haberse dado con anterioridad - en la última asamblea de la Sociedad de Naciones - con un tema tan óptimo, a efectos reivindicativos, como la admisión de México en dicho organismo. Un puyazo, el del columnista, más que oportuno, ya que una propuesta conjunta de los países hispanohablantes, en ese sentido, habría roto la usual «solidaridad retórica» en beneficio del pragmatismo político, dando pie a que el México postrevolucionario encauzase finalmente su vida internacional.

El ejemplo, de cara a futuro, era muy adecuado, ya que «ni Francia ni Inglaterra se avendrían a un reconocimiento que pudiera ser visto con desagrado por Washington», por lo que la responsabilidad debía ser asumida por España y los países hispanoamericanos allí presentes. Y, vistos los precedentes, pocos motivos había para el optimismo, siendo mucho más previsible que se confirmasen los peores presagios de Barcia y la idea acabase derivando hacia la inanidad habitual:

Y si eso sucedió cuando los Estados Unidos permanecen alejados de Europa, piense el lector lo que acarrearía desde el momento en que Norte América practicase con Europa la política del "do ut des". Un hispanoamericanismo eminentemente oratorio o divagador, cuya eficiencia no se proyecte en un sentido depurador y manumitidor, más vale que no exista ${ }^{59}$.

La poquedad exhibida por los países hispanoamericanos en la cuestión mexicana serviría a Barcia para insistir en la incertidumbre en que estos se movían ante la tesitura panamericanismo-hispanoamericanismo. Una opinión compartida, entre otros, por José Ingenieros, quien en un homenaje a Vasconcelos celebrado en Buenos Aires por esas fechas incidiría, precisamente, en la larga huella del intervencionismo norteamericano y en cómo el discurso economicista de Washington escondía los eslabones de una ca-

59 Camilo Barcia, "Sobre el Congreso Hispano-Americano - La abstención de los Estados Unidos”, La Libertad, n. ${ }^{\circ}$ 983, 25 de enero de1923, p. 1. Accesible online. 
dena temible — la de los empréstitos — así como su inevitable secuela: el derecho de intervención.

El peligro empieza, a su juicio, en "la hipoteca progresiva de la independencia nacional mediante los empréstitos”. Con los empréstitos surge el derecho de intervención. La intervención es ya incompatible con la independencia [...] Los gobiernos pueden ya hacer poco, según el Sr. Ingenieros, porque ya están subordinados a la voluntad de los norteamericanos, que son sus prestamistas.

La coyuntura no alimentaba, en el discurso de Ingenieros, más salida que ampararse en el ser colectivo; o, dicho de otro modo, imbuir a los latinoamericanos en un concepto de patria de dimensiones continentales con el que oponerse a un panamericanismo que, de otro modo, parecía imbatible.

"Hay que dirigirse primero a los pueblos y formar en ellos una nueva conciencia nacional", dice el señor Ingenieros. Pero ¿cómo? "Ensanchando el concepto de patria y haciéndolo continental".

Para el Sr. Ingenieros el dilema está, ya, planteado: “O entregarse sumisos y aceptar la Unión Panamericana, o prepararse en común para luchas por la independencia, echando las bases de una Unión Latinoamericana" ${ }^{\circ}$.

Como vemos, el trasfondo político trazado por Ingenieros corroboraría tanto la proposición de Sanín como las dudas de Barcia, lo que, a la postre, no haría sino validar la complejidad del asunto. Esa misma semana, sin ir más lejos, la inauguración del Ateneo de Juventudes Hispano-Americanas, en Madrid, se convirtió en un acto de afirmación en el que la proposición de Sanín no solo recabó apoyos como los del exministro y diputado José Francos Rodríguez o el alcalde de Madrid, Joaquín Ruiz Jiménez, sino que incrementó la apuesta con iniciativas como la creación de una Universidad hispanoamericana ${ }^{61}$. No obstante, al mismo tiempo, la inminencia de la cita panamericana pondría de manifiesto la intrascendencia de la propuesta del colombiano para quienes, sobre el papel, debían impulsarla. Es más, el silencio de los gobiernos latinoamericanos a este respecto contrastaría con la polémica suscitada en esos días entre Chile, Perú y Bolivia tras la negativa del ejecutivo de Santiago a negociar ningún tipo de cesión a cuenta de los territorios anexionados tras la Guerra del Pacífico. Una negativa que provocaría la ausencia de peruanos y bolivianos en la cita santiaguina, a la que habría que sumar la

\footnotetext{
60 "Panamérica o Hispanoamérica", El Sol, n. ${ }^{\circ}$ 1705, 26 de enero de 1923, p. 5. Accesible online.

61 “Afirmación hispano-americana”, $A B C$, n. ${ }^{\circ}$ 6260, 29 de enero de 1923, pp. 15-16. Accesible online.
} 
de un México al que no se le extendería invitación por decisión del gobierno de Washington ${ }^{62}$.

El antagonismo panamericanismo-hispanoamericanismo advertido por Sanín, Barcia e Ingenieros, también sería expuesto por la prensa chilena en los prolegómenos de la Conferencia:

Dos ideales van a ponerse frente a frente, en plazo muy breve, luchando a brazo partido, en guerra de habilidades diplomáticas. El campo de batalla será Santiago de Chile; y los pugilistas serán los principios opuestos del "Panamericanismo", que significa la hegemonía continental norteamericana, con su doctrina paternalista del monroísmo, y el «Hispanoamericanismo», que es la expresión del deseo americano de la igualdad de los pueblos independientes del Nuevo Mundo. Estados Unidos, con todo disimulo, intenta someter a su dirección a las naciones de origen español, convirtiéndolas en satélites de su ambición. El propósito es tan claro que no hay manera de encubrirlo con la superchería de un interés fraternal. Por cierto, y venturosamente es así, que algunas de estas Repúblicas son tan despiertas y altivas, que el intento fracasará63.

El artículo, publicado originalmente en el Diario de Valparaíso, lo firmaba "El Bachiller Alcañices", seudónimo del español Felipe Aparicio Sarabia ${ }^{64}$ y corresponsal de ABC en Chile desde 1916. Es este un detalle interesante en cuanto que revela cómo, pese a todo lo antedicho, las esperanzas estaban puestas en los resultados de la conferencia, lo que - lejos de alentar las expectativas de Sanín - más bien dispondría el tablero en las condiciones más pesimistas previstas por el suspicaz Barcia. Y nunca más a tiempo, ya que los Estados Unidos asumirían como pauta de conducta para la reunión eludir todo asunto que pudiera generar controversia lo que, sobre el papel, evitaba todo cuestionamiento a su política exterior y su hegemonía ${ }^{65}$.

El desarrollo y las conclusiones de la conferencia refrendaron, en cierto modo, la frustración del proyecto de Sanín y el porqué del escepticismo de

${ }^{62} \mathrm{La}$ falta de reconocimiento oficial del gobierno posrevolucionario condenaba a México al ostracismo en este tipo de foros, de ahí la importancia de su reivindicación.

63 "ABC en Sudamérica - La Controversia que se aproxima", $A B C$, n. $^{\circ} 6311,28$ de marzo de 1923, p. 18. Accesible online.

64 Langa Nuño, 2017: 506.

65 Como bien indicaría el entonces Secretario de Estado, Charles Evans Hughes, a la delegación norteamericana: «La agenda de la Conferencia contiene ciertos tópicos que pueden ser considerados controversiales. Debe considerarse que la función de estas Conferencias Panamericanas consiste en tratar en lo posible temas de carácter general no sujetos a controversia». El fragmento es una traducción de las "Instrucciones del Secretario de Estado estadounidense a la delegación norteamericana a la V Conferencia Panamericana", obtenido en Morgenfeld, 2009, Vol. 1: 262. 
Barcia. Valgan tres detalles para ejemplificar lo dicho. El primero sería el fracaso de la propuesta uruguaya para configurar una Sociedad de Naciones Panamericana que estrechase los vínculos entre los miembros de la organización. Una proposición que sería finalmente retirada cuando el debate condujo, como condición previa para su aprobación, a la adopción de la Doctrina Monroe como pauta.

El segundo tuvo que ver con el desencuentro entre las delegaciones brasileña y argentina en torno a la propuesta chilena para frenar la carrera armamentística en el continente. Lo que se planteó como una alternativa para no seguir los pasos de la «paz armada» europea terminó escenificando la desconfianza existente entre las principales potencias regionales, dejando a los Estados Unidos como árbitro de la situación.

Por último, las discrepancias surgidas al albur de una proposición del representante costarricense, Alejandro Alvarado Quirós, en la que plantearía una reorganización de la Unión Panamericana que, entre otros puntos, contemplaba que pudiesen formar parte de la organización representantes distintos a los oficialmente acreditados en Washington. Una proposición que, si bien solventaba el problema mexicano, también arremetía directamente contra la hegemonía norteamericana en la institución, lo que llevaría a la delegación estadounidense a maniobrar entre bambalinas gestando una división entre los asistentes que, a la postre, dilataría un posicionamiento oficial al respecto ${ }^{66}$.

\section{A MODO DE CONCLUSIÓN}

La reunión de Santiago reveló como certezas las dudas de Camilo Barcia y confirmó la división interna latinoamericana - ya fuese natural o inducidacomo el obstáculo por excelencia para todo proyecto unitario como el esbozado por Sanín. Las divergencias a raíz de la propuesta de Alvarado Quirós destaparon una realidad ineludible en lo tocante a una supremacía, la estadounidense, que condicionaba inevitablemente la política continental y el libre ejercicio de la soberanía por parte de las repúblicas latinoamericanas. Tal y como expondría Barcia en referencia a las discrepancias surgidas por la proposición del costarricense: «... tal vez en el fondo de su conciencia los delegados sentíanse solidarizados con Costa Rica; pero no es posible, al parecer, el disgustar a los Estados Unidos de un modo tan incondicionado» ${ }^{67}$.

\footnotetext{
66 Un artículo interesante a este respecto sería Salceda Olivares, 2009.

67 Camilo Barcia Trelles, "La Conferencia Panamericana. Un triste desenlace", España, n. ${ }^{\circ} 370,19$ de mayo de 1923 , p. 12. Accesible online.
} 
La dependencia aludida por Barcia era la misma contra la que Sanín había dirigido sus diatribas, dos-tres lustros antes, al hablar del monroísmo y sus representantes. La misma que ya se apuntaba, allá por 1902, como deriva natural de la política internacional en beneficio de las grandes potencias, criticando el infundado derecho que estas se arrogaban para la tutela de países ajenos y baremando - conforme a dicho panorama - los posibles puntos de encuentro de las repúblicas hispanoamericanas en pos de una suerte de unión por definir. Que veintiún años después, en pleno periodo de entreguerras, propusiese la celebración de un congreso para consensuar una posición común, latinoamericana, frente al nuevo marco geopolítico que parecía decidirse en Europa, no sería sino una reacción lógica dentro de una coyuntura marcada por la reestructuración internacional del poder y el definitivo ascenso de los Estados Unidos de potencia regional a hegemon mundial.

El acervo político e intelectual de Sanín, junto a su amplia experiencia periodística, le dieron el poso suficiente para reconocer la trascendencia del momento y el significado de no estar incluido en foros, como el de Génova, en los que se diseñaba el futuro. Una conjetura que partía de la compleja crisis en que se había sumido Europa tras la Gran Guerra y cuyos efectos amenazaban con extenderse en una espiral de imprevisibles consecuencias. No obstante, el nuevo juego de relaciones y contrapesos implícito a la reorganización del tablero mundial conllevó la internacionalización de códigos bien conocidos por los hispanoamericanos, como la Doctrina Monroe. Que el Pacto de la Sociedad de Naciones aceptase en su articulado una dispensa para dicha doctrina ya desvelaría cómo los nuevos tiempos incluían el mantenimiento de las viejas dependencias, de ahí la desidia de los grandes actores internacionales por pulsar la opinión de quienes, después de todo, eran considerados agentes secundarios dentro del concierto global.

Es conforme a lo expuesto que deben contemplarse la propuesta de Sanín y el discurso de quienes - desde movimientos como el hispanoamericanismo o el antiimperialismo - maniobraron para obstaculizar el predominio estadounidense y su unilateralismo, sobre todo en lo concerniente a América Latina. Del mismo modo, es también desde dicha perspectiva que cabe observar las dudas mostradas por el menor de los Barcia respecto al doble alma de los gobiernos latinoamericanos. Dudas que, en cierto modo, confrontaban las muy distintas actitudes de estos según fuese el foro en el que actuasen de naturaleza hispanoamericanista o panamericanista: fraternos y reivindicativos en los primeros; prudentes hasta la sumisión en los segundos. Cierto es que esto sería una generalización un tanto injusta en cuanto que, haciendo un balance de lo acontecido en las distintas conferencias panamericanas, no fueron infrecuentes los desencuentros vividos por las sucesivas delegaciones estadouni- 
denses. Empero hablaríamos de choques puntuales en los que los representantes norteamericanos, o bien no tuvieron que enfrentar una oposición homogénea, o bien —en los momentos más críticos- supieron encontrar las fisuras y apoyos necesarios para neutralizar las presiones y diferir sus efectos.

El caso de la Conferencia de Santiago resulta significativo, que no único, a este respecto. Baste comprobar cómo su mayor éxito, la Convención Gondra, planteada para concertar un sistema de arbitraje estructurado con el que evitar o prevenir los conflictos entre los miembros de la organización, recibió un aplauso generalizado y el apoyo teórico de los delegados norteamericanos... pero no culminó en un acuerdo que limitase la intervención política o militar de estos en el continente. Así se explica que, pocos meses después de finalizado el encuentro, Sanín volviese a la carga tras hacerse públicas las afirmaciones del Secretario de Estado estadounidense, Charles Evans Hugues, en las que se arrogaría la voluntad de su gobierno de «defender el Canal de Panamá en todas las circunstancias», así como su intención de no obrar de otro modo «con respecto a cualquier otro canal que se construya entre el Atlántico y el Pacífico» ${ }^{68}$. Esto, a ojos del colombiano, ratificaría el desprecio de Washington por la soberanía ajena y el temor de «veinte Repúblicas soberanas e independientes, que oyen pronunciar estas palabras por un secretario de Estado de una nación extranjera, y no dicen esta boca es mía» ${ }^{69}$. Del mismo modo, también así se entiende que, cinco años después, en la Conferencia Panamericana de La Habana, el sentimiento antinorteamericano hubiese crecido exponencialmente a causa del persistente injerencismo estadounidense, plasmándose en el encuentro una nueva contradicción entre las discusiones sobre la aplicación del principio de no intervención acordado en la Conferencia de Jurisconsultos de Río de Janeiro (1917) y las presiones estadounidenses para que su presencia militar en Nicaragua no fuese puesta a debate ${ }^{70}$.

\section{FUENTES}

$A B C$ (Madrid: 1923).

España (Madrid: 1919, 1920, 1923 y 1924).

Hojas Selectas (Barcelona: 1910).

\footnotetext{
68 "El nuevo monroísmo", El Sol, n. ${ }^{\circ}$ 1974, 7 de diciembre de 1923, p. 5. Accesible online.

69 Baldomero Sanín Cano, "Sobre una frase amenazadora de Mr. Hughes", El Sol, n. ${ }^{\circ}$ 1994, 30 de diciembre de 1923, p. 1. Accesible online.

70 Más información en Andrés García, 2017.
} 
La Libertad (Madrid: 1923).

El Sol (Madrid: 1922, 1923).

La Vida Literaria (Madrid: 1899).

Nuestro Tiempo (Madrid: 1902 y 1904).

Unión Ibero-Americana (Madrid: 1924).

\section{Fondos DigitALES}

Almanac of Theodore Roosevelt. URL: http://www.theodore-roosevelt.com. [Última consulta: 13/04/2018]

ABC Hemeroteca. URL: http://hemeroteca.abc.es. [Última consulta: 17/05/2018]

Biblioteca Nacional de España. Hemeroteca Digital. URL: http://www.bne.es/es/ Catalogos/HemerotecaDigital/ [Última consulta: 03/06/2018]

Periodismo Internacional II: Las Grandes Organizaciones Mundiales. Universidad Carlos III OpenCourseWare. URL: http://ocw.uc3m.es/periodismo/periodismointernacional-ii. [Última consulta: 17/05/2018]

Diccionario de Catedráticos Españoles de Derecho (1847-1943). Instituto Figuerola — Universidad Carlos III. URL: http://portal.uc3m.es/portal/page/portal/instituto_ figuerola/programas/phu/diccionariodecatedraticosa: 27/04/2018].

Museo Virtual de Historia de la Masonería. Universidad Nacional de Educación a Distancia. URL: http://www2.uned.es/dpto-hdi/museovirtualhistoriamasoneria/index. htm [Última consulta: 26/04/2018].

Universidad de Buenos Aires. Facultad de Filosofía y Letras. Repositorio institucional: <http://repositorio.filo.uba.ar/> [Última consulta: 17/05/2018].

\section{BIBLIOGRAFÍA}

Andrés García, Manuel, "De la «Patria Grande» a la «Madre Patria»: Manuel Ugarte y el hispanoamericanismo español (1900-1930)", Revista de Indias, LXXIV/261 (Madrid, 2014): 591-622, http://dx.doi.org/10.3989/revindias.2012.020.

Andrés García, Manuel, "Sandino en La Habana: la VI Conferencia Internacional Americana a ojos de la prensa e intelectualidad españolas", Revista Complutense de Historia de América, 43 (Madrid, 2017): 285-306, http://dx.doi.org/10.5209/ RCHA.56735.

Araquistáin, Luis, El peligro yanqui, Madrid, Publicaciones España, 1921. 
Araquistáin, Luis, La revista "España" y la crisis del Estado liberal [Estudio preliminar por Ángeles Barrio], Santander, Universidad de Cantabria, 2001.

Barrios, Miguel Ángel, El latinoamericanismo en el pensamiento político de Manuel Ugarte, Buenos Aires, Biblos, 2007.

Carilla, Emilio, "La revista de Lugones (La Revue Sud-Américaine)", Thesaurus: Boletín del Instituto Caro y Cuervo, XXIX/3 (Bogotá, 1974): 501-525.

Gómez García, Juan Guillermo y Rubiano Muñoz, Rafael, Años de vértigo: Baldomero Sanín Cano y la revista Hispania (1912-1926), Bogotá, Siglo del Hombre Editores, 2016.

Goodwin, Doris Kearns, The Bully Pulpit: Theodore Roosevelt, William Howard Taft, and the Golden Age of Journalism, New York, Simon and Schuster, 2013.

Gracia Pérez, Felipe, Hijos de la Madre Patria. El hispanoamericanismo en la construcción de la identidad nacional colombiana durante la Regeneración (18801900), Zaragoza, Institución Fernando el Católico (CSIC), 2011.

Granados García, Aimer, Debates sobre España. El hispanoamericanismo en México a fines del siglo XIX, México, El Colegio de México/Universidad Autónoma Metropolitana - Unidad Cuajimalpa, 2010.

Granados García, Aimer, "Imaginarios culturales sobre España en la celebración del centenario de la independencia de Colombia", Tomás Pérez Vejo (coord.), Enemigos íntimos. España, lo español y los españoles en la configuración nacional hispanoamericana, 1810-1910, México, El Colegio de México, 2011: 245-272.

Halperín Donghi, Tulio, El espejo de la historia. Problemas argentinos y perspectivas hispanoamericanas, Buenos Aires, Sudamericana, 1987.

Langa Nuño, Concepción, “¿Y las hijas de España? La América española en la propaganda nacional durante la Guerra Civil", Historia y Comunicación Social, 22/2 (Madrid, 2017): 485-510, http://dx.doi.org/10.5209/HICS.57857.

Marcilhacy, David, Raza hispana. Hispanoamericanismo e imaginario nacional en la España de la Restauración, Madrid, Centro de Estudios Políticos y Constitucionales, 2010.

Maya, Rafael, Baldomero Sanín Cano, Bogotá, Academia Antioqueña de la Historia, 1961.

Mora, Luis María, Los contertulios de la Gruta Simbólica, Bogotá, Editorial Minerva, 1936.

Morgenfeld, Leandro Ariel, Argentina frente a Estados Unidos en las conferencias panamericanas 1880-1955, Tesis Doctoral, Universidad de Buenos Aires, 2009, http://repositorio.filo.uba.ar/handle/filodigital/1298

Pérez Monfort, Ricardo, "La intelectualidad conservadora mexicana y Marcelino Menéndez Pelayo. Impresiones de una relación a finales del siglo XIX y principios 
del XX", Aurora Cano Andaluz, Manuel Suárez Cortina y Evelia Trejo Estrada (eds.), Cultura liberal, México y España, 1860-1930, Santander, Universidad de Cantabria, 2010: 277-296.

Pita González, Alexandra, La Unión Latino Americana y el boletín Renovación. Redes intelectuales y revistas culturales en la década de 1920, México DF, El Colegio de México, 2009.

Pita González, Alexandra y Marichal, Carlos, "Introducción: Pensar el antiimperialismo", Alexandra Pita González y Carlos Marichal Salinas (Coord.), Pensar el antiimperialismo: ensayos de historia intelectual latinoamericana, 1900-1930, México DF, El Colegio de México y Universidad de Colima, 2012: 9-40.

Rubiano Muñoz, Rafael, "Baldomero Sanín Cano en La Nación de Buenos Aires (1909-1957). Prensa, diplomacia y análisis político internacional", Historia y Sociedad, 25 (Medellín, julio-diciembre 2013): 79-106.

Salceda Olivares, Juan Manuel, "México y la V Conferencia Panamericana: un campo de batalla diplomática contra el intervencionismo norteamericano"; Tzintzun: Revista de Estudios Históricos, 50 (Morelia, 2009): 61-104.

Sanín Cano, Baldomero, Administración Reyes (1904-1909), Lausana, Impr. Jorge Bridel \& Ca, 1909.

Sanín Cano, Baldomero, De mi vida y otras vidas, Bogotá, Ediciones Revista de América, 1949.

Sanín Cano, Baldomero, El oficio de lector, compilación/prólogo y cronología por Juan Gustavo Cobo Borda, Caracas, Ayacucho, 1978.

Sepúlveda, Isidro, Comunidad Cultural e Hispano-Americanismo, Madrid, UNED, 1994.

Sepúlveda, Isidro, El suelo de la Madre Patria: hispanoamericanismo y nacionalismo, Madrid, Marcial Pons Historia, 2005.

Triviño Anzola, Consuelo, "Baldomero Sanín Cano, fluido, cambiante e inclasificable". Arrabal, 1 (Lleida, 1998): 137-145.

Vélez, Palmira, La historiografia americanista en España, 1755-1936, Madrid, Iberoamericana/Vervuert, 2007.

Fecha de recepción: 12 de junio de 2018.

Fecha de envío de las modificaciones: 20 de julio de 2018.

Fecha de aceptación: 3 de noviembre de 2018. 


\section{Sanin Cano and Spain: anti-imperialism, Americanism and the contingencies of an unsuccessful congress}

Baldomero Sanin Cano is considered one of the main representatives of Contemporary Latin American thinking. Sanin was a prolific writer whose works influenced different fields of essay-writing, journalism, education, politics, and literary criticism. This paper seeks to analyse the ideology of an author who was an advocate of Latin American integration, through his constant opposition to American expansionism in the press. Based on an exploration of his personality, training and political experience, the paper discusses the manifestation of his anti-imperialism in the Spanish media and, in particular, during his time as foreign correspondent in Madrid (1922-1924) for the Argentine newspaper La Nación. It concludes with an analysis of the impact of his proposal to organize an Ibero-American congress in order to form a united front against the Genoa Conference resolutions.

Key words: Sanín Cano; anti-imperialism; Americanism; Pan-Americanism; Hispanic Americanism; Latin America; Continental nationalism. 
